\title{
The Protection of Trademark Rights Against Passing Off Related to Consumer Protection
}

\author{
Imas Rosidawati Wr ${ }^{1}$, Fontian Munzil $^{2}$, Yogi Yogaswara ${ }^{3}$ \\ \{imasrosidawati@uninus.ac.id ${ }^{1}$,fontianm@gmail.com²,yogiyogaswara.mh@gmail.com ${ }^{3}$ \} \\ 1,2,3 Master of Law Studies Program Post-Graduate School, Nusantara Islamic University, \\ Bandung, Indonesia
}

\begin{abstract}
The protection of Intellectual Property Rights is a law enforcement national agenda that is closely related to the international agreement. Indonesia has ratified the WTO and TRIPs, as a consequence, Indonesia must subject to the globalization principles as stipulated in the world agreement and harmonize the provisions of IPR law under the TRIPs Agreement. This paper analyzes the trademark legal protection related to TRIPS ratification of fraudulent acts committed by businesses through passing off as a form of consumer protection. Protection to every right arising from human creativity in commerce and the rapid growth of electronic commerce transactions are increasing along with the rapid pace of people performing imitation/reputation riding of others (passing off). Research method used is normative juridical with descriptive analysis. The study found that Indonesia must prevent any infringement of IPR including the entry of counterfeit and imitation goods primarily within the framework of consumer protection.
\end{abstract}

Keywords: Trademark Rights, Consumer Protection

\section{INTRODUCTION}

The inclusion of the Agreement on Trade Aspects related to IPR (Intellectual Property Rights) in the Agreement on Establishing the World Trade Organization, causing IPR to become one of the most important components in global trade. Consequently, IPR has to follow the globalization principles as regulated in the world's agreement, i.e by extending the scope of the national IPR system. The protection of IPR will improve the developments of the business, trading, and industry within the national and international scopes. Any product obtains the protection of Intellectual Property Rights will have a better competitiveness, therefore, the market will be eventually dominated by high-quality industrial products.

One of the obstacles in providing such protection comes from the Indonesian people itself, which on the one hand still consider IPR as a "public right"[1] that has a social function instead of a private right that needs a protection, this is because there are still many people who do not object if their products are being imitated by other parties. Such a case can be found in Bali, Balinese do not object to imitation, but on the contrary they are proud of their products being imitated, because there is an assumption in which if an original product is being imitated it is because the product itself is really terrific and interesting.[2] 
Trademark owners should diligently protect their trademarks from infringement, dilution and other misuse (e.g., unfair competition, passing off, false advertising, and cybersquatting) that may harm the owner's goodwill and business reputation. At the same time, trademark owners may choose not to vigorously pursue all possible uses that might conflict, or to immediately commence a lawsuit against every possible infringer.[3]

The need for Trademark legal protection has grown rapidly to follow the quick pace of people riding other's fame [4], this is because wellknown Trademark products are the fastest selling products in the market, thus riding other's fame will bring relatively bigger profits faster. The attempt to gain profits that way violates the business ethics, moral norms, and even breaks the law. Passing off constitutes the use of entire or substantial registered trademark belonging to another person or another legal entity without having the rights to use the trademark. The action of using such a Trademark or sign is considered as unhealthy competition (unfair competition).

If you do register a trademark and you find someone copying you, then enlist specialist help from the start. Trademark infringement and passing off are complex areas of law. Get them wrong and you can lose your trademark or even worse, be sued by someone else first. When it comes to protecting your brand, it is better to be proactive than reactive. This allows you to determine your next move, and not have it determined for you by the other side [5].

In TRIPs (Trade-Related Intellectual Properties) is mentioned that the member countries are required to implement the provisions on the trademark use as an effort to protect the consumers from becoming the trademark imitation victims. For example, in the case of Nike in Indonesia, the Supreme Court of the Republic of Indonesia has argued that the use of the international wellknown trademark without permission could deceive the consumers, it is as if the counterfeit goods are the original ones, whereas the counterfeit goods may have lower quality compared to the original ones. In addition, the regulations contained in GATT (General Agreement on Tariffs and Trade) require to include the indicator of the origin of the imported goods as an effort to protect consumers.

Trademark counterfeiting has become a constraint on trade and investment, thus enforcing the trademark law is a commitment that has to be fulfilled as a consequence for Indonesia being the member of WTO. Trademark rights are the important factors in creating a fair trading system. Trademark is used in trading activities of goods or services, it is also to distinguish similar goods or services from one company to the another [6], thus, trademark prevents the business behavior from harming the consumers and enables the provisions on consumer protection to be obeyed by the related parties.

Currently, the use of a trademark without permission (trademark counterfeit) needs to be watched out considering there are possible subversive elements through counterfeiting of medicines, foods, beverages, cosmetics and other goods, furthermore, using other's well-known trademark can undermine the government policy in the economic field. The IIPA [7] has recommended 41 countries as having the predicate of Priority Watch List or Watch List country, this recommendation is intended for monitoring purpose under the Article 306 of Trade Law, USA. In that report, Indonesia was given a predicate as a priority watch list country along with nine other countries (Argentina, Canada, Chile, China, Costa Rica India, Russia, Thailand, and Ukraine). Countries in the Priority Watch List are rated by the Office of the United States Trade Representative (USTR) as countries with a "serious IPR violation" and thus require a bigger attention [8].

Unethical practices will bring moral hazards in various economic and political sectors borne by all nation elements. The moral hazard issues are sufficiently large and deep, and on the broader scale, the moral and ethical factors should be included as important economic variables, 
especially in the patterns of economic and business behaviors [9]. The behavior of business actors in the globalization era supported by the advanced telecommunication and information technology causes the transactions of goods and services to get through the country's borders faster and widespread. [10]

In the maintenance of economic continuity, the consumers occupy an important position, however as the economic actors, the consumers have a very weak position in terms of legal protection [11]. This weak position is due to, among others, lower consumer awareness in Indonesia, difficulty in law enforcement to supervise the manufacturers especially in the relation with filing a lawsuit regarding losses suffered by consumers [12].

\section{METHOD}

The research method used is normative juridical with descriptive analysis specifications to provide data that is as accurate as possible and actual.[13] Collection technique is library research activities carried out by collecting problem references including legislative material that is directly related to the problem being studied. Stages of library research are activities for collecting primary legal material data within the scope of legal protection of intellectual property related to the ratification of WTO and TRIPs by Indonesia. Normative juridical research is also used to examine the vertical and horizontal synchronization of existing legislation. Data will be analyzed qualitatively juridically, then it will be elaborated and presented in a structured and scientific manner so that the problem can be elaborated analytically descriptively.

\section{RESULT AND DISCUSSION}

\subsection{Trademark Protection In The Relation With Counterfeit And Passing Off}

The definition of counterfeit goods under article 51 of TRIPS, defined as follows: [14]

"Counterfeit trademark goods shall mean any goods, including packaging, identical to a validly registered trademark in respect of such goods, or the trademark essential aspects cannot be distinguished from the registered trademark, thereby considered an infringement to the owner of the trademark in question under the law"

With the development of a market economy, the common law evolved to protect markets and promote good behaviour by extending legal protection for the reputation of goods, title, trade identity and dress. The law thus guarded competitors' economic interests against impropriety and misrepresentation [15]. The primary function of a trademark is to distinguish between goods and services, i.e to act as a 'badge of origin'. By fulfilling this function, the trademark has two primary objectives, first is to protect the goodwill and reputation of the traders who have registered their trademarks and, second is to prevent the public from being deceived regarding the origin of goods or services [16].

Many jurisdictions also recognize the action of passing off. In this instance, trademark registration is not a requirement, it is all about one company having a reputation in a name or brand, and another company causing consumer confusion through the use of a similar name or brand [17]. The reasons of why counterfeiting business is increasing, among others: The high amount of profits, the high profits are more easily achieved compared to the amount of investment and costs spent on counterfeiting activities.;Due to the advanced technology, highquality counterfeit and pirated goods can be easily produced by the counterfeiters; Syndicates or criminal groups are likely to support the distribution or the financial of counterfeit goods. Especially for well-known trademark goods; and Ineffective law enforcement of the country, meanwhile, the counterfeit goods may be centered and circulated within the said country. [18] 
From the point of view above, it is needed to establish a rule of law to provide a trademark protection not only for the trademark holders but also for the consumers, it is important to protect trademark to guarantee of the goods quality and to increase the goods appeals for the consumers. Trademark protection is also important to maintain the credibility of the people who are engaged in the productions or sales, against other unauthorized parties.

Trademark law aids consumers who use trademarks in the marketplace to identify swiftly and without problems, a product they liked or disliked in the past, distinguishing among the different competing manufacturers of a product. Trademark protection promotes three main policies : Protection of the trademark holder's goodwill; Protection of the consumer; and Economic efficiency [19]. In line with the economic globalization, the trading of goods and services has rapidly increased, therefore the international harmonization of IPR system has become very important. The IPR system in each country is different and has its own legal consequences. The counterfeiting and imitation issues have become a serious problem for industries and economies around the world.[20] Counterfeiting affects the industries, national economies and human lives as the consumers, as in cases : In Nigeria, 109 children died after taking pharmaceutical preparations containing paracetamol and industrial solvent in 1990. [21] The cases above were only several of various cases occurring around the world, the important thing to note is that the 'counterfeit goods often end up in death'.

Counterfeit goods are harmful to the national and/or global economies and its presence is also harmful to the owners of trademark rights as well as to consumers in general because they cause major losses to the global economy due to the circulation of counterfeit goods. Each year around 3-7 percents of the total amount of the circulating goods are counterfeit ones and the total loss to the global economy is estimated at around 70-80 million US dollars annually. To inhibit the circulation of counterfeit goods in the market, the IPR holders have to endure heavy burdens on official costs, such as the costs in prohibiting the production, distribution, export, and import of the counterfeit goods, which would not have been required if counterfeiting does not occur. For consumers, it is very risky if the purchased goods have a lower quality than expected and it is impossible for the consumers to have the purchased goods repaired or replaced by the manufacturer if the damaged goods are still in a relatively good condition.

The TRIPs Agreement regulates the obligation of its members to provide legal procedure and efforts in their national laws to ensure an effective IPR enforcement. Speaking of "enforcement", it is usually regarding the law enforcement in which the country uses criminal sanctions against people who violate the rights of others.

Criminal actions regarding Trademark have been regulated separately in Law Number 20 Year 2016 on Trademarks and Geographical Indications, with a maximum imprisonment of 5 (five) years and or a maximum fine of $\mathrm{Rp} 2,000,000,000.00$ (two billion rupiahs) for impersonating or using the same trademark entirely. And a maximum imprisonment of 10 (ten) years and or a maximum fine of Rp 5,000,000,000.00 (five billion rupiahs) for impersonating of goods resulting in health problems, environmental disturbances, and/or death. Violation of the articles with a penalty and/or fine is considered as a criminal offense (klacht delict). This means only with a report or klacht from the trademark owners, then the offenders will be prosecuted and subject to sanctions or held an investigation.

\subsection{The Consumer Protection On Trademark Rights In Indonesia}

In today's free-trading era, all parties are required to think realistically that goods and services from other countries should be able to enter Indonesia. This entrance raises a problem if there is a consumer complaint on the imported goods and services, besides, there are many imported original or counterfeit goods and even local goods whose distributors in Indonesia are 
still unclear. This lack of clarity makes it difficult for the consumers if they experience losses by using the products or services. TRIPs (Trade Related Intellectual Properties) states that the member countries must implement provisions on trademark use as an effort to protect consumers from becoming trademark imitation victims. To protect consumers, therefore Law Number 8 Year 1999 on Consumer Protection is enacted. The consumer protection is based on the existing number of consumer (legal) rights that need to be protected from harmful actions performed by unauthorized parties, thus its fulfillment is necessary to be guaranteed by the country.

A trademark as the part of intellectual property is characterized by a property of ideas or expressions [22], this trademark property is an essential tool in e-commerce and used for preventing other parties from giving misdirection to the consumers regarding products of a company who has no authority (not originate). This unhealthy competition also occurs on the internet, especially in the domain name that often uses company names, trademarks, and services owned by others without permission.[23] A violation occurs when the party without having trademark permission, registering the trademark as their own domain name on the internet network. The actions of passing off are regarded as an unfair competition under Article 10 bis of the Paris Convention, encompassing any action that creates confusion as well as any misleading statement (false allegation) to discredit their competitors, in addition any indication or declaration of any practice in the opposite of honest trading activity is regarded as an unfair competition. Indonesia as a member of Paris Convention must ensure the effective protection in the national law against any unfair competition which may cause harm to the other parties. By ensuring effective protection, it is expected to prevent or suppress any action causing unfair competition.

Parties who experience loss due to passing off may file a lawsuit, which in the Common Law system is known as "The action for Passing off". According to Copinger:[24]

"The action for passing off lies where the defendant has represented to the public that his goods or business are the goods or business of the plaintiff. A defendant may make himself liable to this action by publishing a work under the same title as the plaintiff's, or by publishing a work where "get up" so resemble that of the plaintiff's work as to deceive the public into the belief that it is the plaintiff's work, or is associated or connected with the plaintiff".

According to the definition above, Copinger argues five characteristics as excuses for people to do "passing off", namely : a misrepresentation, made by a trader in the course of trade, to prospective customers of his or ultimate consumers of goods or services supplied by him, which is calculated to injure the business or goodwill of another trader (in the sense that this is a reasonably foreseeable consequence), and which causes actual damage to a business or goodwill or the trade by whom the action is brought or, in a quotient action, will probably do so. [25]

Based on results of the study, it was found that trademark reputation riding (passing off) caused harm to some parties, consumers who feel deceived because the quality and comfort of the goods are not in accordance with the desired ones. Legitimate manufacturers and/or trademark owners suffer material losses as their output/turnover decreases, and they may also lose the society's trust. The country will incur losses because the Perpetrators do not pay the taxes that should be paid as an income to the state finance such as Corporate Tax, Employee Tax, and other obligations. Trademark reputation riding may also damage the trading relationship between the Republic of Indonesia and other countries, especially regarding the use of well-known trademarks.

As an effort to improve the law enforcement of IP (Intellectual Property) regarding the consumer protection in order to develop and strengthen the national IP system, the Directorate General of IP requires work and coordination together with all related parties including 
government institutions, universities, Research and Development Institute, NGOs, and private sectors. In recent years, the technological aspects have clearly dominated the IPR. Information technology issues with "e" facilities and the Internet have become common problems and the law enforcement has also faced information technological problems.

\section{CONCLUSION}

As for the closing, the conclusions the author is pointing out are : Indonesia must prevent any infringement of intellectual property rights including the entry of counterfeit and imitation goods primarily within the framework of consumer protection. The law enforcement should be done in an integrated manner between various related institutions such as customs, commercial courts, and other supporting institutions. The opportunity to simplify licenses can reduce the counterfeiting and piracy problems. The consumer legal protection of counterfeit goods under the Consumer Protection Law has not been fully realized, therefore, to ensure the enforcement of consumer rights, the consumer empowerment efforts are needed as well as guidance and supervision on the implementation of consumer protection. Finally, compliance with the Consumer Protection Law relies on the legal awareness of the public, especially on the law enforcement apparatus and all the important elements involved in implementing the regulation, particularly regarding consumer protection. The efforts required to enhance the IPR law Enforcement in relation to consumer protection are performed namely through IPR Network Expansion and Public Education and Awareness.

\section{ACKNOWLEDGMENTS}

Master of Law Studies Program Post-Graduate School of Islamic University of Nusantara, Bandung, Indonesia. This research is funded by DIPA Kopertis Region IV West Java Banten, Ministry of Research, Technology and Higher Education, in accordance with Letter of Agreement of Research of Decentralized Grant Research Fiscal Year 2018 Higher Education Research Program of Higher Education Number: 0030-B/LPPM-UIN/11/2018.

\section{REFERENCES}

[1]. Cita Citrawinda Priapantya, Budaya Hukum Indonesia Menghadapi Globalisasi: Studi Kasus Perlindungan Rahasia Dagang Farmasi, it is explained that in other developing countries such as China, IPR is often considered as a "public right".

[2]. Imas Rosidawati, Pengetahuan Tradisional dan Hak Kekayaan Intelektual, Refika Aditama, Bandung, p. 7, 2017

[3]. Oliver Herzfeld and Michael S Mayer, "Trademark Licensing Background of the Case Collegiate Licensing," no. February, pp. 25-27, 2017

[4]. Abdulkadir Muhammad, Kajian Hukum Ekonomi Hak Kekayan Intelektual, Citra Aditya Bhakti, Bandung, p. 218, 2011

[5]. Paolo Beconcini, "Counterfeit Corner.," Licensing Journal 34, no. 1, 2014, pp. 24-26, http://ezproxy.eafit.edu.co/login?url=http://search.ebscohost.com/login.aspx?direct=tru $\mathrm{e} \& \mathrm{db}=$ lgh\&AN=93994251\&lang=es\&site=eds-live

[6]. Tim Lindsey et all. (editor), Hak Kekayaan Intelektual Suatu Pengantar, Alumni, Bandung, p. 132, 2017

[7]. See "International Intellectual Property Alliance (IIPA), February 10, 2012 
[8]. The Office of the United States Trade Representative (USTR) is an institution in the United States who is responsible for recommending trade-related policies in the United States.

[9]. Stephen Haggard, The Political Economy of the Asian Financial Crisis (Washington: Institute for International Economics, pp. 15-16, 2000

[10]. Ahmad M. Ramli, Cyber Law Dan HAKI Dalam Sistem Hukum Indonesia, Refika Aditama, Bandung, p. 4, 2012

[11]. Gunawan Widjaya and Ahmad Yani, Hukum tentang Perlindungan Konsumen, Publisher Jakarta, Gramedia Pustaka Utama, p. 12, 2007

[12]. Supreme Court of Indonesia \& the Faculty of Law of Indonesia, Hukum Perlindungan Konsumen, UI Press, p. 200, 2015

[13]. Soerjono Soekanto dan Sri Mamudji, Penelitian Hukum Normatif Suatu Tinjauan Singkat, Raja Grafindo Persada, Jakarta. p. 14, 2012

[14]. JICA, Capacity Building Program on the Implementasi of the WTO Agreements in Indonesia, Cooperation of Directorate General of IPR of Ministry of Law and Human Rights with Japan International Cooperation Agency Jakarta, p. 89, 2004

[15]. Bita Amani and Carys Craig, "The 'Jus ' of Use : Trademarks in Transition," n.d.

[16]. Lisa P. Ramsey, Free Speech and International Obligations to Protect Trademarks, The Yale Journal of International Law, Volume 35, Number 1, Winter, p. 416, 2010

[17]. Ilse Plessis, Southern District Court, and Case No, "Brand Licensing The Beatles: Issues," no. January, pp. 18-20, 2016

[18]. "Trademark Management in Enterprises" Asia Pacific industrial Property Center, Jape Institute of Invention and Innovation (JIII) 2009.

[19]. Georgios I Zekos, "Intellectual Property Rights: A Legal and Economic Investigation.," IUP Journal of Knowledge Management 14, no. 3, pp. 28-71, 2016, http://search.ebscohost.com/login.aspx?direct=true $\& d b=b t h \& A N=117530105 \&$ site $=$ eh ost-live

[20]. Colin Davies \& Tania Cheng, Intellectual Property Law in the United Kingdom, Kluwer International BV, Netherlands, 2011, page

[21]. JICA, op. cit., p. 94

[22]. Morris, Julian, Rosalind Mowatt, W Duncan Reekie, Richard Tren. Ideal Matter: Globalisation and the Intellectual Property Debate, Centre for the New Europe. See also Garima Gupta \& Avih Rastogi, Intellectual Property Rights: Theory \& Indian Practice, Working Paper Series, Centre for Civil Society, p. 2, accessed on May 13, 2011.

[23]. D. Shyamala, Domain name- Trademark conflict Resolution: An Evaluation of UDRP (The Uniform Domain Name Dispute Resolution Policy), Australian Intellectual Property journal, Volume 21 / 1, p. 44, March 2010

[24]. See Bainbridge, David I, Introduction to Information Technology Law, Pearson Longman, UK, p. 202, 2008

[25]. Copinger, Skone James, Copyright, Twelfth Edition., London : Sweet \& Maxwell, p. 328, 1980, in Muhamad Djumhana \& R. Djubaedillah, Op. Cit., p. 237 